\title{
Orbital Sarcoma Pathologic TNM Finding v8
}

National Cancer Institute

\section{Source}

National Cancer Institute. Orbital Sarcoma Pathologic TNM Finding v8. NCI Thesaurus.

Code C140837.

A pathologic finding about one or more characteristics of orbital sarcoma, following the rules of the TNM AJCC V8 classification system. 